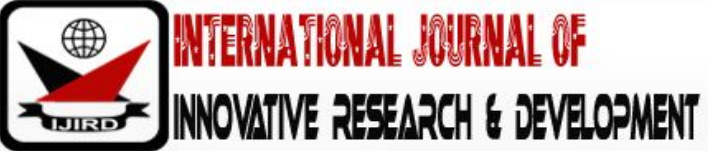

ISSN 2278 - 0211 (Online)

\section{Poor Public Policy Formulation and Its Effect on Policy Sustainability in Nigeria: An Appraisal of Monetization Policy of Obasanjo's Administration}

\author{
Chidi Ukomadu \\ Lecturer, Department of Public Administration, Dorben Polytechnic, Garam, Nigeria \\ Dr. Itodo Sylvanus Mohammed \\ Lecturer, Department of Public Administration, Nasarawa State University, Nigeria
}

\begin{abstract}
:
Public policy is one of the instruments deployed by the government to realize its objectives; it is supposed to be a process that involves several stages that should be adhered to, as each stage contributes to its acceptance, understanding and eventual implantability and sustainability. This paper is aimed at appraising the relationship between poor policy formulation and its effect on sustainability in Nigeria, with special focus on the Monetization policy of the Obasanjo administration. The paper adopted content analysis as its methodology, where it examined several literatures on the subject matter and drew conclusion based on the findings. Some of the findings are : the formulation of monetization policy was faulted, it was elitist in its approach,The real beneficiaries or the segment of the population it will impact on the most were not carried along in the formulation process. Again, the resumption of construction of residential accommodation for federal civil servants by the Office of the Head of Service of the Federation is an indication of the unsustainability of the monetization policy. Some of the recommendations include: Policy formulation should be backed by serious research and evaluation and Government and policy makers should avoid making unnecessary and frivolous pronouncements or embarking on policies, programmes and projects without proper and adequate feasibility study
\end{abstract}

Keywords: Public service, policy formulation, sustainability, monetization policy, policy process

\section{Introduction}

Policy formulation is a stage in the policy process. According to Nwekeaku (2014), this involves identifying the problem, analysis of the problem, implications, rules and regulations concerning the issue, as well as selecting the principles that are in consonant with the objectives. He further opined that the formulation stage involves asking of questions such as; what are the cost implications? Who are the beneficiaries? What are the consequences of this policy? What are the best options for this policy? Is it in public interest? Etc, Generally speaking, publicpolicy as a concept has several definitions; public policies are the policies adopted and implemented by government bodies and officials. Mekwa (1976), sees public policy as "official statements determining the plan of action or what the government wants to do. Ikelegbe (1996), sees it as what government choose to do or not to do. It is the integrated courses and programme of action that government has set and the framework or guide it has designed to direct actions and practices in certain problem areas".

Generally, public policy is purposive and goal-oriented, as it is designed to achieve a particular objective, a guide for government and its agencies actions and decisions which affect the public ora section of it, positive or negative, as every programme schedules, as well as the implementation agency.Nwekeaku (2014) recognized policy making as a process and not a one- time event, he posited that policy making is a dynamic process involving series of interactions, actions, decisions and reactions of the actors and citizens who are engaged in an interactive continuum. The policy making process according to him includes

\subsection{Policy Formulation}

This involves identifying the problem, analysis of the problem, implications, rules and regulations concerning the issue, as well as selecting the principles that are in consonant with our objectives. The formulation stage involves asking of questions, such as what are the cost implications? Who are the beneficiaries? What are the consequences of this policy? What are the best options for this policy? Is it in public interest? Etc.

Answers to the above questions help the policy makers to fine-tune the policy and put it into action.

\subsection{Policy Promulgation}

After formulating a policy, it is communicated to the department or level of the organisations where it is applicable for necessary actions. This is the stage a policy is adopted, legitimatized and legally fine-tuned for implementation. Intense 
lobbying by powerful interest groups, mutilation and manipulation of the policy are the major characteristics of this stage. It is at this stage that the outcome of lobbying, negotiations and manipulations are empaneled into law or edict for implementation.

\subsection{Policy Education}

After promulgating a policy, who are affected by the policy need to be properly briefed, enlightened and education on the policy for their understanding, cooperation and support. Workshops, seminars and conferences could be mounted for proper policy education. Induction or orientation programme may facilitate policy education. When people understand a policy properly, they are better placed to support it or even to make constructive criticism of the policy.

\subsection{Policy Acceptance}

When people understand a policy, they may cooperate and support its implementation. When they cooperate with the implantation authority or agency, the policy is said to be accepted. Active involvement of the people at the formulation state facilitates policy education and acceptance. A wide consultation and active participation of major stakeholders in formulating a policy, enhances its acceptance, popularity and implementation.

\subsection{Policy Implementation}

This is the stage a policy is put to test or task for formal execution. It is put into force or practice. The agency or agencies for the implementation go into action, as the policy is implementation go into action, as the policy is implemented in the field. The initial period of policy application is usually a critical one for policy makers because if the policy fails to achieve its expected results, it then means that the policy maker did not do a good job of studying the problem and he environment in order to come up with a good policy (Obiajulu and Obi, 2004). Similarly, Anderson (1975), observed that policy is to say being made as it is being administered as it is being made.

\subsection{Policy Control}

This is usually a mechanism put in place to ensure that all institutions, departments, units or persons involved in the implementation of a policy play their roles well. Line managers or supervisors are usually giving the responsibilities of monitoring and supervising the policy implementation to ensure strict compliance with the conditions and specifications of the policy. Peoples' actions, assignments and conducts are strictly regulated for the attainment of the set objectives.

\subsection{Policy Evaluation}

The policy is put to scale here and assessed against the set objective. The objectives, the strategies, the programmes and other important segments and elements of the policy are analyzed and evaluated. It is at this stage that the strength and weaknesses of the policy are x-rayed and noted. The entire performance of the policy is determined at this stage.

\subsection{Feedback}

Evaluation of a policy reveals all areas that are problematic, defective and challenging that need to be amended or completely overhauled, for expected progress. This may lead to an overhaul of the objectives, the strategies and even the programmes for better performance and expected results.

The first stage, which is the formulation stage is very important in that it sets the tone of the policy, a lot of research and analysis is required at the stage if the policy is to succeed. If the policy promoters did not get it right at the formulation stage, implementation will be a herculean task. Commenting on failure of policies in Nigeria, Maduagwu (2017) said, "Take up any past or present policies of government. How many of them were efficiently and effectively implemented? This is true of the Universal Primary Education (UPE), introduced by Obasanjo as the Military of Nigeria in 1976 and its current successor, Universal Basic Education (UBE), the Operation Feed the Nation (OFN) and the Ethical Revolution of Shagari's administration; the War Against Indiscipline (WAI) of Buhari military regime; the Vision 20:20:20 of Obasanjo's government, the Seven-point Agenda of the late President Yar'Adua and the Transformation Agenda of President Jonathan. Continuing, Maduagwu argued that, "in Nigeria, as in many other parts of theworld, experience has shown that in most cases, policy makers put the cart before the horse. First, policies are pronounced before attention is paid to the questions of whether, who, how, what, where and so on. In other words, government makes a policy statement. Thereafter, public and civil servants are saddled with the task of justifying the policy, forcing the policy to work, suggesting ways and means so on.

Little wonder there has been dissonance between policy formulation and implementation in Nigeria over many years, spanning across several administrations, both military and civilian, leading to policy summersault and policy abortions This paper therefore tries to establish a link between poor policy formulation on the part of Obasanjo's government and the watered-down and the lame implementation of the Monetization policy earlier introduced by the administration.

\section{Conceptual framework}

\subsection{The Concept of Public Policy}

Like most concepts in the social sciences, there is no consensus among experts on the true meaning of the public policy and at that, it has many definitions, in an attempt by scholars to find an acceptable definition of the concept. An understanding of public policy requires an examination of the activities of government and those who govern (Hill, 1993). 
Public policy then is "an officially expressed intention backed by a sanction, which can be a reward or a punishment." As a course of action (or inaction), a public policy can take the form of "a law, a rule, a statute, an edict, a regulation or an order" (Lowi and Ginsburg 1996). Ayo (1985), defined public policy as any "action taken by the government in pursuit of certain aims". It is further defined by Mekwa (1976), as "official statements determining the plan of action or what the government wants to do". After citing the definitions of many other experts on policy studies like Robert Simmons, Duncan Mavrae Jr, Robert Presthus, Jacob and Flink, Kenneth Prewiti and Heinz Eulau, Ikelegbe (2014), gave a simplistic definition. According to him, public policy is a course of action or programme of actions which is chosen from among several alternatives by certain policy actors in response to certain problems". Ikelegbe went further to expatiate on this definition. According to him, public policy has the following five characteristics:

- A policy involves a choice. It is an important or major choice taken by individuals, groups or organizations. This choice is made from several available alternatives.

- A policy is a proposed course of action, projected set of decisions or statement of future actions. A policy states what is going to be done or would be done and outlines a course of contemplated or desired action in relation to certain desired objective or events in the real world.

- A policy is goal oriented and directed at the attainment of certain purposes or intentions, objectives and end states.

- A policy has to do with particular needs, problems or problem areas. It is not a fictional response to abstract issues or problems, but rather responds to the challenges and pressures arising from an environment. In fact, often times, a policy is designed and targeted at resolving specific existing or future problems or satisfying certain needs.

- A policy provides the framework within which present and future actions are undertaken. A policy is a course setting action that provides the direction, the guide and the way to the achievement of certain goals.

\subsection{Types of Public Policy}

Nwekeaku (2014), citing Theodore (1964) and Mckinney and Lawrence (1979), classified public policy thus:

\subsubsection{Distributive Policy}

This is a policy made to ameliorate, designed to appease, accommodate and compensate a section of the public or give them the impression that government is objective and wants to address their problem. This is a favour, patronage and distributive policy, designed for resources distribution in the society.

Distributive policies are meant for specific segments of the society, it could be in the area of grant of goods, public welfare or health services etc. These mainly include all public assistance and welfare programmes, food relief, social insurance, vaccination campaign programmes etc. This distributive policy focuses on government concern for equal access to resources and also promotes private action

The key distinguishing feature of distributive policies is that it does not generate conflict among those seeking to benefit from the policy. This arises from the fact that the distribution is continual and those that lose out initially are almost certain of gaining later. If people perceive that there is a measure of impartiality and fairness in the distribution, people are bound to wait for their turn.

\subsubsection{Redistributive Policy}

These are policies which relate to relations between or among classes or segments of the population, such as the unemployed, homeless, disadvantaged, poor, the retired, etc

Redistributive policies are concerned with the re-arrangement of policies which are concerned with bringing about basic social and economic changes. Certain public goods and welfare services are not equally divided among certain segments of the society. These goods and services are streamlined through redistributive policies.

This policy is designed to redistribute public resources, in order to bridge the inequality or wealth differentials in the society. Examples of redistributive policies are Pay as you earn (PAYE), tax concessions, mass transportation services and government subsidies on social services, which are designed to bridge the inequality (gap) in the society.

\subsubsection{Regulatory Policy}

This policy is designed to regulate and sanitize the economy in order to avoid confusion and abuse of the process. It is arrived at reducing the inside abuse through a regulatory framework, such as tariffs import/ custom duties among others, designed to regulate the economic behavior, such as excessive consumption of imported foreign products. Regulatory policies are concerned with regulation of trade, business, safety measures, public utilities etc.

This type of regulation is done by independent organisations that work on behalf of the government like NAFDAC, Central Bank, National Environmental Safety Regulatory Agency (NESREA), Standards Organisation of Nigeria (SON) etc. The policies made by the government pertaining to these services and organisations rendering them are known as regulatory policies.

\subsubsection{Innovative Policy}

This policy is designed to stimulate creativity or innovation among the citizens. The National Economic Empowerment and Development Strategy (NEEDS) is an example of innovative policy. It was designed to improve resource allocation and utilization in the society. 


\subsubsection{Functional Policy}

This is a functional or operational policy, designed to assist in the implementation of public programmes or administrative decisions. It is a minor policy with direct relationship or link with regulations and guidelines.

It is a policy decision that is consequent upon administrative discretion and reactions to diverse situations and challenges in the polity.

\subsubsection{Fundamental Policy}

This is a policy that affects issues that are very crucial in the state and are based on the constitutional provisions or judicial interpretation, among others. Fundamental policy is relatively rigid and not easily amended.

\subsubsection{Substantive Policy}

This type of policy is targeted at making positive impact on the lives of the citizens of the society. Examples of this policy include Deregulation, Commercialization, Liberalization, etc. This type of policy is not easily amended because of the usual interest it generates.

\subsubsection{Major Policy}

This is a policy that derives its existence from legislative enactments, especially from the National Assembly. A major policy may be in the form of law passed by the National Assembly, which may insist on the implementation of the programme undiluted. For instance, not quite long ago, the National Assembly adopted a motion and urged the Minister of the FCT to urgently remove speed bumps, which according to them are dangerous. The FCT Minister complied immediately and removed those bumps.

\subsubsection{Symbolic Policy}

This is a non-controversial public policy that neither threatens the status quo, nor cause any major upheaval or challenges in the polity as it is merely symbolic, designed to offer psychological relief to the citizenry.

It is a policy designed to give succor or a sense of belonging to the members of the system but does not have capacity to bring revolutionary or fundamental changes in the polity. It is designed to give impression to the people that the government is interested in their problems and welfare, even if it does not bring any fundamental changes in their lives.

For example, policies on mass literacy, health for all, rural development etc, are mere symbols to give the impression that the government is working.

\subsection{The Concept of Monetization}

Adekeye (2003), sees monetization as a "withdrawal of direct funding of the basic amenities of the public servants by the government". The Office of the Secretary to the Government of the Federation, (2006), defines Monetization as the quantification in money terms of those fringe benefits which government used to provide for its workers as part of their conditions of service: Such benefits include residential accommodation, chauffeur-driven cars, residential furniture, utility services, etc.

This policy was introduced in June 2003, while implementation started with political office holders, including ministers and members of the National Assembly. The policy was subsequently extended, first to the core civil service and is being extended to all arms of the public service. The policy was partly aimed at reducing the cost of government, eliminating sources of wastage and leakages while at once helping officers to prepare for life after retirement through encouragement of a savings and investment culture. This policy quantified in monetary terms, those fringe benefits provided for workers as part of their conditions of service. Consequently, the following benefits were monetized: residential accommodation, transport, furniture, medical, utility, domestic servants, leave grant, meal subsidy, duty tour and fuelling/maintenance.

The introduction of the monetization policy by President Obasanjo was informed by the fact that at the end of 2001, over 85 percent of public sector expenditure went to overheads costs. It has been asserted that one major way of ensuring good governance is to adopt public policy that is capable of minimizing fraud, preventing wasteful use of public funds and facilities, as well as checking abuse of power by public officials.

The Obasanjo regime reasoned that there was an urgent need to take a hard look at these incredible fringe benefits and allowances in order to check the spiraling cost of providing them; which have been gulping enormous resources that could have been otherwise used for social capital projects for the generality of Nigerians. The policy on Monetization was therefore adopted by the government to stem the ever -rising annual expenditure outlay on the benefits provided for public servants, so as to reduce waste. For instance, it costs government a lot of funds to construct, purchase or rent residential accommodation for public servants.

Again, large amounts of resources were occasionally spent on renovation, maintenance and furnishing of these residential accommodations, as well ason the purchase, fuelling and maintenance of official vehicles for public servants. It was also evident that some public officers maintain many official vehicles in a variety of brands which were liable to various forms of abuse apart from the high maintenance costs.

The monetization Policy has far reaching impact on government planning, budgeting and fiscal discipline, and would positively impact on the national value systems and ethics. Thus, the policy has the following benefits according to Makinwa (2016): 
- Enables government to get the true picture of what it costs to maintain a political office holder or public servant in office, and therefore lead to a more realistic budgeting and budget implementation;

- Provides the most transparent avenue for disbursement of remuneration and fringe benefits from employers to employees;

- Curbs the excess of public officers. For example, unlike in the past, political office holders are now to drive to office and back in their personal cars with their personal drivers;

- Corrects the wrong public perception of government utilities such as telephone, electricity etc as limitless resources which hitherto were used without caution;

- Stops the practice where, in renovating official quarters and changing furniture items, the discarded items were in many cases not accounted for, giving room for abuse;

- Minimizes unauthorized journeys at government expense;

- Ensures equity in the allocation of scare resources; h).Ensures that public officers develop and imbibe discipline culture of frugal use of public utilities;

- Encourages public officers to own their vehicles, houses, furniture and thereby assist them to plan better for their retirement;

- Enables the public servants to plan for a more comfortable post-service life; and

- Encourages increased productivity because of the euphoria of increased income.

By far, the most important advantage of the policy on the economy is the fact that the revenue realized from savings occasioned by Monetization would be invested in capital development to improve the wellbeing of the entire citizenry.In spite of the lofty benefits offered by the policy, there are also a number of challenges that besetting the implementation of the reform. These include:

- The need to phase out certain cadres in the Civil Service who become redundant due to the policy, e.g.Drivers attached to officers hitherto entitled to chauffeur-driven vehicles. Some drivers, notably those attached to car pools, convoy, CVU and staff buses, will still remain. The phasing out of the rest of this cadre has lots of social and economic implications that would require careful management;

- The mobilization of the sizeable amount of resources required to fund the terminal benefits and entitlements of the drivers that would be let go as a result of the monetization policy. In the immediate term, this can amount to quite a huge sum of money;

- The need to re-train a number of other cadres, if the yare to remain useful and relevant to the service. This also requires resources, time and resolve;

- The need to develop equitable criteria for the disposal of the assets, for example, government -owned houses that would become available for sale as a result of the policy. There is the challenge of balancing the requirement to get market value on the affected public assets and the need to give some consideration to public servants, whose emoluments have not always been market-driven over the years; equal opportunity to bid for these assets;

$>$ There is also the challenge of re-orientation, i.e. getting public officers to realize that it is "no longer business as usual" as far as the enjoyment of the benefits-in-kind that they were used to is concerned. The resultant "withdrawal syndrome" has to be managed. Just like the components of some other public reforms, the initiative of the policy cut across the following areas:

$>$ Poverty reduction;

$>$ Strengthening and improving the delivery of basic services;

$>$ Control of public expenditure by reducing waste; and

$>$ Checking corruption and abuse of power.

He emphasized that most workers would have been able to acquire such essential property while in service, and thereby escape the trauma their predecessors experienced during post-service years.

\section{Empirical Literature Review}

Contributing on the raging debate on why policies fail in Nigeria, Maduagwu (2017), raised a poser; "why have there been several cases of policy failures in Nigeria?". He went ahead to catalogues some policies that failed in the past like Agricultural policy, Refinery Management Policy, Electricity Policy and Steel Industry policy, to name a few, he advanced two reasons for the constant policy failures or lack of policy sustainability in Nigeria which include: 1. Colonial heritage of civil service and 2. the so-called "Nigerian factor".

Talking about the colonial heritage of the civil service and its negative effect on policy formulation and implementation, Maduagwu posited that our public servants and by extension, policy makers sees the civil service as the "white man's" job, that serves the interest of the colonial authorities and certainly not the Nigerian interest. Even at independence, this notion still persisted, there is not much difference between the earlier characterization and the term, "government job", which most of us prefer to use today. The point being made is that the colonial origin of the Nigerian civil service has a negative impact on the development of that system. The colonial heritage may have given rise to seemingly very negative attitude to s0-called government thing by many Nigerian public servants. Maduagwu (2017) concluded by saying that if we hope to ever be able to efficiently and effectively formulate and implement policies and programmes, we have to find a way of purging ourselves from the colonial mentality of regarding government policies and programmes as if they were alien or external to our own personal affairs.

The second factor identified by Maduagwu as the bane of sustainable policies in Nigeria is what he called "the Nigerian factor", which according to him connotes negative attributes of Nigerian behavior from harmless to very serious 
ones. It could be a euphemism for corruption, for discrimination on the basis of ethnic or religious belonging, for irresponsibility, for cheating, for disregard for law and regulations, etc- but always in a negative sense. Ekwoaba in Walson-Jack (2008) simply put it as a way of getting things done in the Nigerian way. When we talk of the "Nigerian factor" in our system, we mean negation of standard rules of procedures (or behavior) expected of person(s) who operate within the system. He concluded by positing that the Nigerian factor finds itself in ethnicity, favouritism, corruption, selfishness, circumvention of rules, regulations or laws of the land, abuse of power, smuggling, rigging of elections, intimidation/ suppression, judicial maneuvering, corner-corner acts etc.

From all indications, the Nigerian factor which is a euphemism for corruption, disregard for law and regulations etc, as observed by Maduagwu (2017) and Ekwoaba in Walson-Jack (2008), reared its ugly head in the formulation of the Monetization policy which made its implementation a herculean task, leading to policy summersault it is experiencing currently.

According to Akinkugbe et al (2013), President Obasanjo was determined on curbing corruption in the public sector, leading to one of the earliest bills to the National Assembly-the Independent Corrupt Practices and Allied Offences Commission (ICPC) bill. Obasanjo believed that in order to in order to have the moral courage to call on civil servants to curb corruption; he had to look into their salaries. In May 2000, he affected 125-250\% increases to the salary of civil servants. This initial salary increase led to the ballooning of the government's recurrent expenditure, such that the recurrent-capital budget ratio which was 33:66 in favour of capital vote under the military administration was reversed to 65:35. The president realized that some existing cadres had indeed become moribund due to extant policies and that majority of personal benefits (like renting and furnishing of accommodation, provision of vehicles, medical treatment, etc), were a huge drain on government and their dispensation was short on equity and transparency. So he decided. So he directed that those benefits be monetized. Government official vehicles were withdrawn and sold to civil servants at 50\% discount after depreciation. A total of 4,400 drivers affected by the policy were released and paid off but the disengaged drivers were deliberately made to benefit from the sale of the official vehicles with which many of them were able to start their personal transport businesses.

El-Rufai (2013), stated that all benefits-in-kind like free housing, furnishing, car and drivers for various cadres of public servants and political office holders were abolished for ministers, permanent secretaries and equivalent cadres and below. All government owned houses, except thirteen classes of official residences were sold to occupants or via public bids. All official vehicles were discounted by $50 \%$ and sold to officials. Other pool andutility vehicles were auctioned in public bids. Personal drivers, cooks and cleaners were laid off and made personal staff of the affected officials. Akinkugbe et al (2013), posited that perhaps, the most applauded of the monetization implementation aspect of the Obasanjo public service reform was the sale of government houses to public servant occupants. The houses were sold at 'replacement cost' (i.e., excluding the cost of the land and infrastructure.

In his research, Makinwa (2016), surmised that the criticism against the policy by the respondents showed that though the policy was lofty but badly implemented. It therefore invariably did not add much value as envisaged or initially made known to the workers. Some of the objectives of the policy were that it would enhance the living standard of the workers by not only enhancing their pays, but also made them property owners in terms of houses, land or cars. Though, the policy enhanced the personal emoluments of the workers, the attendant high inflation accompanied the propaganda made nonsense of their purchasing power.

For a good example, the housing rents in the nation's capital, the Federal Capital Territory (FCT), Abuja; all the state capitals of the Federation; and their satellite towns witnessed geometrical inflation of about $350 \%$. The bitter truth is that these innocent workers could not afford the rents from the so called monetization policy as they have to access rent payment year in year out from the commercial, micro -finance banks or co-operative (thrift) societies. This is being paid back by deductions from their salary accounts in the banks. This high inflation cuts across all other basic amenities, goods and services, hence the policy has impoverished the workers. Today, poverty is easily perceived in the lives of many Nigerian workers on their countenance, what they wear, eat, the houses they live in, the condition of their cars, how they talk, the way they walk, and even the type of prayers they offer.

Tied up to the inclement situation of the Nigerian workers highlighted above, as revealed from the study is that, those of them that own cars have turned the cars into commercial use. Many of the workers could not afford to rent apartment alone. It was revealed that two or three workers would contribute money together to rent a house and share the rooms among themselves. This situation highlighted above were isolated cases before the introduction of the monetization policy in 2003, but now a common occurrence in Nigeria.

One critical thrust of the policy was the government's resolve to dispose the government houses being occupied by workers before the policy to the occupants of such houses. Unexpectedly, these residential houses were offered to workers atoutrageous cost beyond their reach. Initially, they were asked to pay $10 \%$ of the cost of such houses for commitment while subsequent payments would be directly deducted from the workers' salaries for between 10 to 15 years period. Against this expectation, the government directed the house occupiers to private Finance Houses for mortgage loans. The Finance houses and mortgage banks paid en-bloc the costs of the houses to the Government. The fate of the workers are now left in the hands of the Finance Houses who are now paying through their noses because of high interest rate, administrative cost and other charges. They have also been mandated to move their salary accounts from the conventional banks to the various finance and mortgage banks. The respondents claimed that at the end of each month, they are only left with pitiable stipends for the survival with their families.

The researcher also discovered that as a result of this unpleasant situation, many workers have personally disposed their houses to offset their loans, and used the remaining amount to build small apartments in satellite towns or villages, far from their working place, which incidentally also affects their punctuality and performance at their work 
places. The workers who did not benefit from the government houses confessed that the monetization policy has hiked up the rent rates, especially in the FCT, which is the seat of government. This is contrary to the expectation of the workers as assured by government that the policy would crash down house rents, making it to be cheaper. The policy as initially conceived wanted to pay the monetization benefits en-bloc every year like it obtains in the private sector or the classified government parastatals, against its being spread to twelve (12) calendar months now. As a result of this, the workers lacked huge liquidity cash to buy houses or build their own.

It was revealed that poor productivity culture which is prevalent in the Nigerian public service is a function of many interwoven variables that are both intrinsic and extrinsic in nature. The haphazard implementation of the monetization policy significantly heightened the poor productivity drive in the public sector. The policy dashed the hope and high expectation of improved living standard.

The policy document on monetization expected that the policy would reduce waste, cost of government and corruption in the public administration. Findings showed that instead of these, the cost of governance and corruption is still on the high side; hence the government has set up the Oronsanya Committee which submitted its report recently on how the cost of governance could be reduced. Corrupt practices in different nature are still prevalent in the public sector which has been the bane of national development in Nigeria. Thus, the policy has not achieved its objectives in this direction. The savings the government were expected in the implementation of the policy to prosecute more capital or developmental projects in the country were not forthcoming since the cost of governance and corruption have not abated, but rather on the increase.

This inability to achieve the original objective for which it was introduced has led to policy reversal and summersault from what is being observed in the public service recently. In a research conducted by Ini Ekot of the Premium Times, it was discovered that most Ministries Department and Agencies have started buying vehicles again for their top officials. He reported that "now evidences have shown that days after the uproar over presidential cars, dozens of government ministers and hundreds of Heads of agencies began taking delivery of the same kind of cars senators acquired, in breach of the monetization policy". Continuing he said that hundreds of the officials are today chauffeured in the 2012 Toyota Prado or Land Cruiser. Over several weeks, Premium Times tracked over 90, while the Directorate of Road Transport Services confirmed registering another 57 in less than six months in Abuja alone, while hundreds are said to be by the Federal Road Safety Corps (Ini Ekot,2012).

According tojimoh (2017), The Head of the Civil Service of the Federation HoCSF), Mrs. Winifred Oyo-Ita said about 16,000 Federal Civil Servants who participated in the Federal Integrated Staff Housing (FISH) Property Fair would benefit from the first phase of the mass housing scheme. She said while the FISH program is strategic initiative designed purposely as an intervention project for massive housing delivery to federal civil servants, it is also a Special Purpose Vehicle (SPV) for housing delivery for federal workers and is being driven by strategic partnership involving relevant ministries, Extra-Ministerial Departments (MDAs) and National Pension Commission (PENCOM) among others.

\section{Findings}

In view of the reviewed literature, it was discovered that the formulation of monetization policy was faulted, it was elitist in its approach. The real beneficiaries or the segment of the population it will impact on the most were not carried along in the formulation process. According to Nwekeaku (2014), after policy formulation in the policy process, what follows is policy promulgation, where the policy is communicated to the department or level of the organisations where it is applicable for necessary actions. This is the stage a policy is adopted, legitimatized and legally fine-tuned for implementation. After that comes the Policy education stage. In this, those who are affected by the policy need to be properly briefed, enlightened and education on the policy for their understanding, cooperation and support. Workshops, seminars and conferences could be mounted for proper policy education. Induction or orientation programme may facilitate policy education. When people understand a policy properly, they are better placed to support it or even to make constructive criticism of the policy. Before policy implementation stage, Policy acceptance stage is the next stage. When people understand a policy, they may cooperate and support its implementation. When they cooperate with the implementation authority or agency, the policy is said to be accepted. Active involvement of the people at the formulation state facilitates policy education and acceptance. A wide consultation and active participation of major stakeholders in formulating a policy, enhances its acceptance, popularity and implementation. The Monetization policy was designed by top echelon of the civil service without carrying the whole services along, hence its present unsustainability and attendant policy summersault.

At the time of his departure from office in 2007, President Olusegun Obasanjo was shocked to find out the magnitude of the monetization of the legislators and the jumbo salaries they were to earn. He refused to sign the bill, leaving it for President Yar'Adua who signed it eventually in other to please the legislators. The monetization policy, a policy that was meant to solve a problem has now created more problems, it is now like a monster. The question then becomes, is the monetization policy sustainable, given the economic downturn staring at the nation? Another indication of a shoddy job, poor policy formulation before rushing into implementation, making its sustainability a herculean task.

One of the critical components of the Monetization policy was the sale of government buildings, this was to eliminate the cost of renovations of those buildings and reduce the cost of governance in the long run. But recently, the Office of the Head of Service of the Federation in conjunction with private investors and other Ministries, Departments and Agencies are floating the Federal Integrated Staff Housing (FISH), an initiative designed purposely as an intervention project for massive housing delivery to federal civil servants. Though this is a partnership with the private investors, billions of naira will leave the coffers of these various MDAs in support of the initiative. 
The Office of the Head of the civil service is aware of the difficulties being faced by federal workers as a result of the sale of government quarters in Abuja, Lagos and other state capitals.Most of the workers who couldn't pay for the houses they were occupying ad to personally dispose their houses to offset their loans and used the remaining amount to build small apartments in satellite towns or villages, far from their working place which incidentally affected their punctuality and performance at their work places. The haphazard implementation of the monetization policy in no small way, significantly heightened the poor productivity drive in the public sector.

\section{Methodology}

This research work employed content analysis as its methodology and therefore relies on the existing literature germane to the formulation and implementation of the monetization policy in the federal civil service, from where the researcher drew conclusions.

\section{Conclusion}

Based on the findings above, one can conclude that the monetization policy is not sustainable, partly to the fact that there was shoddy formulation process before the implementation, this led to a lot of reversals or policy summersault, an indication that the committee did not take a critical look at the nitty-gritty of the policy and carried critical stakeholders along before rushing into implementation, thereby leading to non-sustainability of the policy.

The policy document on monetization expected that the policy would curb waste, cost of governance and corruption in public sector administration. Findings showed that instead of these, the cost of governance and corruption is still on the high side. Thiswas what led to the setting up of the Oronsanye Committee on the how the cost of governance could be reduced.

\section{Recommendations}

Based on the findings and conclusions above, the researcher proffered these recommendations which when implemented, will lead to sustainability and implementability of policies, as against the incessant policy reversals and summersault being experienced in the country.

The recommendations include:

- Policy formulation should be backed by serious research and evaluation, care must be taken to ensure that government agencies and officials charged with formulation and implementation must be adequately equipped for the job.

- Policy makers should understand that policy making is a process and not an event and at that, due diligence must be followed to ensure that no stage is skipped, as they all contribute in making the policies strong, acceptable, understandable and implementable.

- Government and policy makers should avoid making unnecessary and frivolous pronouncements or embarking on policies, programmes and projects without proper and adequate feasibility study. Nigeria has become a burial ground of policies and programmes, abandoned mid- way because of lack of proper study and mostly, after huge sums of money have been committed towards its implementation

\section{References}

i. Adekeye, F, (2003), "Walking Down the Monetised Rope”, Newswatch, Monday December 8

ii. Akinkugbe, O, Joda, A, Ibidapo-Obe, O, Okonofua, F. and Idowu, B ed,(2013), Olusegun Obasanjo: The Presidential Legacy, 1999-2007, Vol 1, Ibadan: Bookcraft.

iii. Ayo, E. J. (1985), Development Planningin Nigeria, Ibadan: University Press Ltd.

iv. Ekot, I. (2012), "Ministers Violate Monetization Policy, Illegally Spend Billions on Exotic Cars", PREMIUM TIMES, October 12.

v. El-Rufai, N. A, (2013), The Accidental Public Servant, Ibadan: Safari Books

vi. Ikelegbe, A.O, (1996), Public Policy Making and Analysis, Benin: Uri Publishing Ltd

vii. Maduagwu, M.O, (2017), Public Policy Formulation and Implementation in Nigeria: Challenges and the Way Forward, Induction Lecture Delivered at 2017 Institute of Policy Management Development (IPMD) Induction and Awards, International Conference Centre Abuja.

viii. Makinwa, T. F, (2016), "Challenges and Prospects of Monetization Policy in Nigerian Public Service”, International Journal of Educational Research and Reviews, Vol.4 (6), pp743-751 June

ix. Mlekwa, V.(1976), "Policy and Practice in Adult Education: A District Case Study", Utafiti Vol.1 No.2

x. Nwekeaku, C.E. (2014), Public Administration Principles and Theory, Abuja: Ogunmileye Press Nig. Ltd.

xi. Obiajulu, S.O and Obi, E.A, (2004),Public Administration in Nigeria: A Development Approach, Onitsha: Bookpoint Ltd.

xii. Office of the Head Service of the Federation (2006), May, 1 (3)

xiii. Olaopa, T (2012), Public Administration and Civil Service Reforms in Nigeria, Ibadan: Bookcraft. 